\title{
Hybrid DSS for recommendations of halal culinary tourism West Sumatra
}

\author{
Mardison, Agung Ramadhanu, Larissa Navia Rani, Sofika Enggari \\ Department of Information Systems, Computer Science Faculty, Universitas Putra Indonesia YPTK Padang, West \\ Sumatra, Indonesia
}

\begin{tabular}{|c|c|}
\hline Article Info & ABSTRACT \\
\hline Article history: & \multirow{10}{*}{$\begin{array}{l}\text { Decision support system (DSS) is a system that design to support managers } \\
\text { in deciding on multiple criteria and multiple attributes. This study combines } \\
\text { two methods in the DSS, that are analytical hierarchy process (AHP) method } \\
\text { and simple additive weighting (SAW) method. This combination of two DSS } \\
\text { method named hybrid DSS. The AHP method is using to find the weighting } \\
\text { or priorities of criteria in DSS and then the value will use by SAW method } \\
\text { using to find the decision. The decision of this DSS is the recommendation of } \\
\text { halal culinary tourism in West Sumatra Indonesia. The purpose of this study } \\
\text { is to provide updates from previous studies, related to adding indicators of } \\
\text { halal culinary tourism and other information updates. The number of } \\
\text { potential culinary tourism attractions and tourism, the problems that exist in } \\
\text { the real field, is still lack of culinary information in West Sumatra. As a } \\
\text { result, many tourists find it difficult to find the best and economical culinary. } \\
\text { The SAW and AHP methods become the hybrid DSS method that will be } \\
\text { able to classify and provide information on halal tourism in West Sumatra } \\
\text { that is precise, accurate, consistent, and validated. }\end{array}$} \\
\hline Received Mar 3, 2020 & \\
\hline Revised Dec 9, 2020 & \\
\hline Accepted Mar 20, 2021 & \\
\hline Keywords: & \\
\hline Analytical hierarchy process & \\
\hline Halal culinary & \\
\hline Hybrid DSS & \\
\hline Simple additive weighting & \\
\hline Tourism & \\
\hline
\end{tabular}

This is an open access article under the $\underline{C C B Y-S A}$ license.

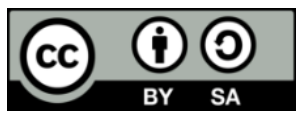

\section{Corresponding Author:}

Agung Ramadhanu

Department of Information System

Computer Science Faculty

Universitas Putra Indonesia YPTK Padang

Jl. Raya Lubuk Begalung, Padang, Sumatera Barat, Indonesia

Email: agung_ramadhanu@upiyptk.ac.id

\section{INTRODUCTION}

Culinary tourism is now a type of tourism that has much impact on the development of a region. One of the critical values is to develop the possibility of authentic regional foods that seem to have begun to be displaced by foreign products or ethnic cuisine oriented. For this reason, an effort must be made to increase this economic potential by providing touch or support to be able to attract local or foreign tourists to enjoy the authentic regional cuisine [1]. During this time, when discussing and showing the location of the culinary center, often, the information obtained is only limited to the street name and the direction or characteristics of the region. The clarity of the culinary center location is not mapped correctly [2]. Strategic, inexpensive, and convenient food places are one of the final components in determining the desired culinary location. Culinary tourism is now an exciting thing in tourist cities such as Padang, where Padang is a city and, at the same time, the capital of the province of West Sumatra, Indonesia. As the largest city in the province of West Sumatra, Padang is filled with various tribes. With those various types of ethnicity between ethnic groups and cultures, food appetite is significant in determining the location and place to eat in the city of Padang. Utilization of the multi-attribute decision making (MADM) method can be used to help people 
make decisions quickly, precisely, and consistently [3], [4]. MADM is specifically designed to support someone who has to make individual decisions [5]-[7].

MADM is a branch of the operations research model that deals with decision making. The implementation of this method is used to find the best opinion from several alternatives, which contradict each other based on the decision criteria. This model is usually used to select a limited number of alternatives. Decision support systems are very well implemented to solve semi-structured problems. In conducting an assessment usually uses linguistic preferences. This study tries to apply a combination of analytical hierarchy process (AHP) [8] and simple additive weighting (SAW) [9] methods in making halal culinary tourism recommendations in West Sumatra.

The AHP method was developed by Saaty and is used to solve complex problems where there is very little data, and statistical information on the problem faced. AHP method, which is often also known as the term AHP is a form of decision-making model with multiple criteria [10]. One of AHP's reliabilities is that it can carry out simultaneous and integrated analyzes of qualitative or even quantitative parameters. The leading equipment of this model is a functional hierarchy with the primary input is human perception. A complex and unstructured problem is broken down into groups, and the groups become a form of hierarchy [11].

The process carried out by the SAW method in making decisions is known as the weighted sum method. The basic concept of SAW method is to find a weighted sum of the performance ratings for each alternative on all attributes [12]. On the issue of this study about the unsuitable house, renovation assistance is distinguished by several assessment criteria, namely: the condition of the house, the number of dependents parents, working parents, the number of income parents, the status of the child. Based on the assessment criteria determined above, each of these criteria can be weighted, requires a process of normalization of the decision matrix to a scale that can compare with all alternatives rating available, then do the ranking process. With the ranking method, it is expected that the assessment will be more precise because it is based on a predetermined criterion and weight so that it will get more accurate results on who will receive unsuitable house renovation assistance [13], [14].

Recapitulation of data collection used the method of direct interviews by researchers to owners of restaurants in West Sumatra. The data collected were based on nine predetermined evaluation criteria. They are halal certificates issued by Majelis Ulama Indonesia (MUI)/Indonesia Ulama Committee owned by restaurants whether their status is there, is being processed or not. The other criteria are available food and beverage specifications, favorite foods, favorite drinks, number of visitors per day, food prices, age segments of visitors, facilities, and online indexes. The number of restaurants visited by researchers was as much as +51 in West Sumatra. Each restaurant visited has its advantages, such as the Grilled Fish Haru Restaurant, which specifications are Gurami grilled fish, Tilapia grilled fish, Coral sea grilled fish. Whereas the first Lamun Ombak Restaurant located on Street S. Parman No. 232 A Ulak Karang, which has two branches, namely Street Khatib Sulaiman No. 99 and Padang Bukittinggi Km. 24, have different specifications, namely Snapper Fish Curry, fried chicken, pop chicken, beef soup, spicy and sour meat, shrimp, and others.

Hybrid decision support system (HDSS) with the method of analytical hierarchy process (AHP) and simple additive weighting (SAW) in recent years is increasingly being used in research. The combination of these two methods is very closely related to solve the semi-structured problem in the decision-making system [15]. The analytical hierarchy process method is known as a hierarchical pairwise comparison criterion and is very consistent in determining priority or weight values using the consistency ratio formula if $\mathrm{CR}<0.1$, then the pairwise comparison values are consistent [16], [17]. The weight value will be used later in the sum of the preference values using the SAW method [18], [19]. The SAW method is known as the weighting sum through the calculation of the normalization matrix, and the final ranking results where the value of the highest alternative is chosen as the best solution.

The solution of the combination of the AHP method and SAW used in processing halal culinary tourism data in West Sumatra can recommend several halal labeled restaurants [20], [21]. The restaurants have good food and drink specifications, many visitors, complete facilities, and affordable prices. This HDSS system is implemented into an android mobile application that can ease visitors of West Sumatra to determine halal culinary tourism easily.

The purpose of this study is to provide recommendations to tourists in finding halal food in a special place in the West Sumatra area of Indonesia. With this DSS, tourists who are not familiar with the West Sumatra region will find it easier to find halal cuisine in the area. The recommendation is obtained from the calculation used in the DSS method by using a combination of the AHP and SAW methods so it is called Hybrid DSS. AHP method is used to determine the weight of each criterion then the SAW method is used to calculate the decision. The data in this study were taken from all famous halal restaurants located in West Sumatra. 


\section{RESEARCH METHOD}

To guide the preparation of the study, it is necessary to have a bright framework for the stages. At the beginning we do is determine the definition of the problem. Next, we did a literature review. After understanding the problems and reviewing the literature we collect data and information in the field. Furthermore, the data that has been collected is processed using a HDSS with the AHP and SAW methods. After the results are obtained, implement and evaluate the system. The Figure 1 is a research framework that we conducted.

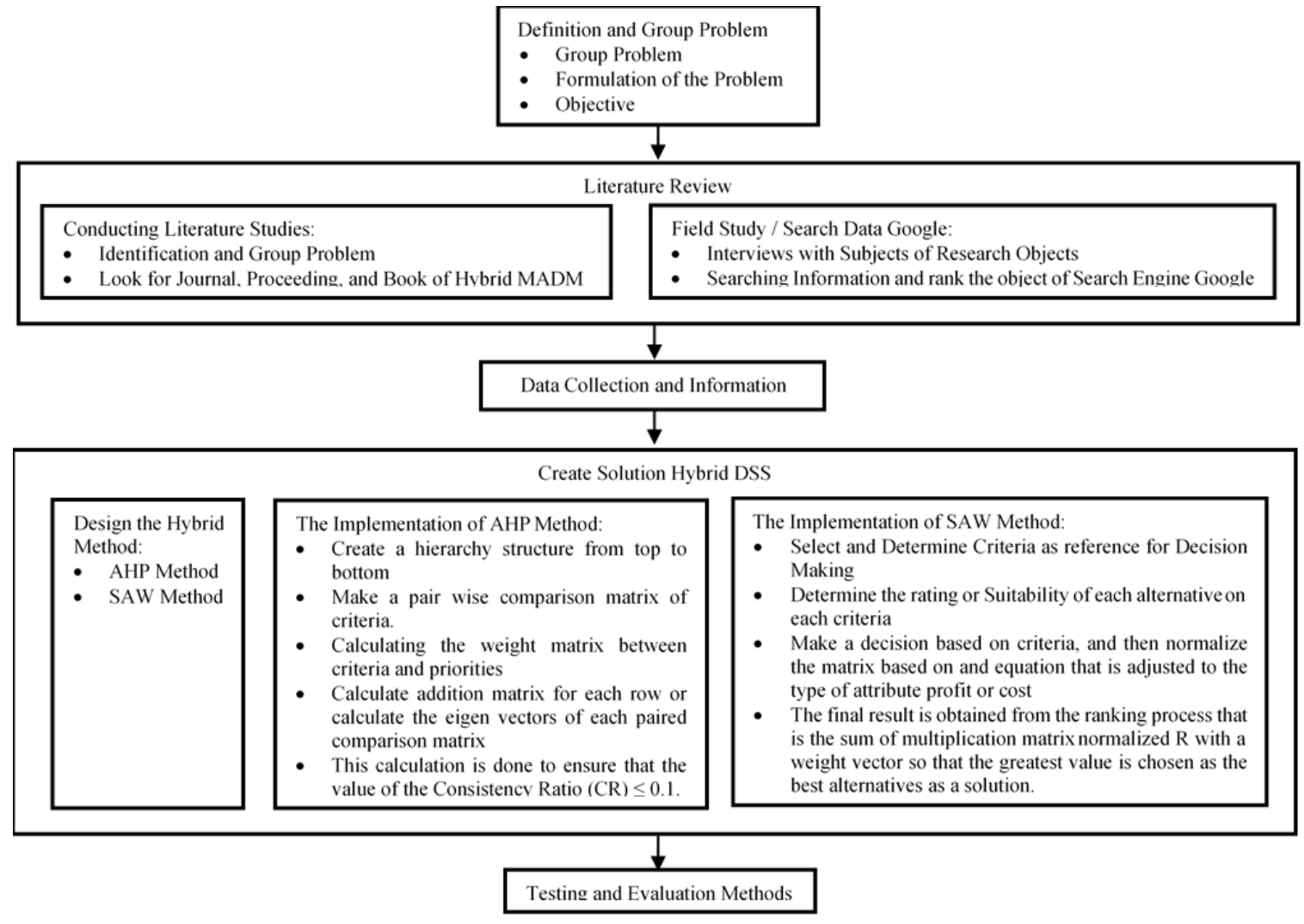

Figure 1. Research framework

1. Definition and group problems

a. Group problem. The main thing that must be determined in the definition of segmentation and grouping of problems lies in when the researcher wants to make a selection and grouping of problems to be studied because with that it can help researchers to focus and facilitate researchers on what problems they want to solve or create solutions [22].

b. Formulation of the problem. After the researcher has grouped the problem, what to do next is to formulate the problem by inserting it into the problem cluster table, to create some core problem items that will be formed into the formulation of the problem [23].

c. Objective. Based on the formulation of the problems, the objective phase is useful to clarify the framework targeted from this research. Objectives are what is the solution that will be produced to solve the problems.

2. Literature review

In studying literature studies, there are two stages:

a. Conducting literature studies by starting from the completion of identification and grouping of problems, the thing done is to look for literacy journals, proceedings, and books about the AHP method and the SAW method; it is useful to obtain references and literature that supports the research process.

b. Field study/search data google, field studies/search data google that the authors do, namely:

- Observation and interview, namely, conducting a direct question and answer with one of the research subjects responsible for managing the research object. 
- Searching information and ranking the research object, this is the power and effort of researchers to obtain Resource Information that can be processed as research material to make it more real and complex.

3. Data collection and information

After we do a literature review as good enough, then we should collect the data and information from the field. The data and information that we collect are about halal culinary tourism in West Sumatra Indonesia.

4. Create solution HDSS

In create solution HDSS, there are three stages:

a. Design the Hybrid Method. Because this study is hybrid DSS then we use two designs of DSS they are a design of DSS using AHP Method after that continued design of DSS using SAW Method.

- AHP Method. The AHP Method is an acronym of Analytical Hierarchy Process Method. The AHP Method is the first method used to design this hybrid DSS. The AHP method is using to find the weighting or priorities of this hybrid DSS.

- SAW Method. The SAW Method is an acronym of Simple Additive Weighted Method. The SAW Method is the second method used to design hybrid DSS. The SAW method using the weighting or priorities that have been found by AHP method to find the decision of hybrid DSS.

b. The Implementation of AHP Method:

To implementation the AHP method we need 5 steps, namely:

- Create a hierarchy structure from top to bottom. The hierarchy structure is from top to bottom, from the top hierarchy is objectives the below layer is criteria of DSS and the last bottom layer is alternatives that will choose in the DSS.

- Make a pairwise comparison matrix of criteria. The value of the pairwise comparison of criteria and the value of pairwise comparison came from the head or principal or expert about the problem. In this study, the criteria of halal culinary tourism and the value of pairwise comparison came from Indonesia Ulama Council (MUI) Region West Sumatra.

- Calculating the weighting of matrix between criteria and priorities. Calculating the value in a way using the pairwise comparison table. Each value is a divide with the summing of every column at that value exist.

- Calculate the addition matrix for each row or calculate the eigenvectors of each paired comparison matrix. The eigenvectors determine the consistency ratio.

- $\quad$ This calculation is done to ensure that the value of the Consistency Ratio $(\mathrm{CR}) \leq 0.1$

c. The Implementation of SAW Method

- Select and Determine Criteria as a reference for Decision Making. The criteria in SAW method is the same with AHP method so that we don't need to make new criteria.

- Determine the rating of each alternative on each criterion. The rating of each alternative we use the priorities value that the result from AHP method.

- Make a decision based on criteria, and then normalize the matrix based on an equation that is adjusted to the type of attribute profit or cost. The benefit criteria and cost criteria are determined by the head or principal or expert about the problem. The formula that using to normalize the matrix of criteria namely: Benefit Criteria: Cost Criteria:

$$
\begin{aligned}
& r_{i j}=\frac{X_{i j}}{\operatorname{Max}_{i} x_{i j}} \\
& r_{i j}=\frac{\operatorname{Min}_{i} x_{i j}}{x_{i j}}
\end{aligned}
$$

- The final result is obtained from the ranking process that is the sum of multiplication matrix normalized $\mathrm{R}$ with a weight vector so that the greatest value is chosen as the best alternatives as a solution. The value to find the decision namely:

$$
\mathrm{V}_{\mathrm{i}}=\sum_{\mathrm{j}=1}^{\mathrm{n}} \mathrm{W}_{\mathrm{j}} \mathrm{r}_{\mathrm{ij}}
$$

Int J Artif Intell, Vol. 10, No. 2, June 2021: 273 - 283 
- Testing and evaluation methods. After we get the decision as to the solution of the problem then we testing that decision in the real world and evaluating the result of testing. In this study the testing and evaluation doing to tourist that looking for halal culinary in West Sumatra Indonesia and the restaurant that serves halal culinary in West Sumatra.

\section{RESULT AND DISCUSSION}

This research resulted in a decision support system for selecting the best computer-based librarians. The system built used the hybrid MADM model, which is a combination of the AHP and SAW methods. In producing the best alternative, the system accommodates the involvement of many decision-makers (group decision making). AHP method is used for weighting and SAW for the ranking process. The system steps to produce halal culinary tourism recommendations in West Sumatra are is:

\subsection{Determining the match criteria rating value \\ 3.1.1. Halal certificate criteria $(\mathrm{C} 1)$}

The culinary industry has quite high prospects. Creation and innovation also need to continue to attract longer and more consumer interest. It is essential to remember that consumers tend to be bored with food or drinks [24]. Concerning the consumption of halal food, the halal process of food and drink is required to meet the requirements and procedures for the halal guarantee system set by MUI. The assessment of halal food certificate [25] is based on certificates already issued by, being in the administration process, being submitted, and none at all. Each assessment has a grade and rating according to the specified assessment range [26]. As shown in Table 1.

\subsubsection{Criteria for food and beverage specifications (C2)}

Every culinary food and drink Padang Restaurant is very diverse. Besides many similarities, each region in West Sumatra also has a somewhat different cuisine variant compared to other regions. Like Restaurant A, there are nine types of food such as Fried Chicken, Rendang, Snapper Curry, Pop Chicken, Spicy Sour Meat, Beef, Spinach, Grilled Fish, Gado-Gado, and four types of drinks such as Ice Cream, Fruit Soup, Ice Juice, and Sweet tea. As shown in Table 2.

Table 1. Composition of halal food assessment

\begin{tabular}{ccc}
\hline Certificate & Grade & Rating \\
\hline Issued & Very Good & 3 \\
Being processed & Good & 2 \\
None & Poor & 1 \\
\hline
\end{tabular}

Table 2. Composition of food specifications assessment

\begin{tabular}{ccc}
\hline Number of food specifications & Grade & Rating \\
\hline$>14$ & Excellent & 4 \\
$8-13$ & Very Good & 3 \\
$4-7$ & Good & 2 \\
$1-3$ & Poor & 1 \\
\hline
\end{tabular}

\subsubsection{Favorite food criteria $(\mathrm{C} 3)$}

West Sumatra is famous for its culinary wealth. A variety of typical foods of West Sumatra have a distinctive taste that is popular and worldwide. The complete menu is ranging from Rendang, Spicy Sour, Brain Curry, Chili Shrimp, and Pop Chicken. With delicious flavors, Padang's culinary tourism destination is never empty of visitors. As shown in Table 3.

\subsubsection{Favorite drinks criteria $(\mathbf{C} 4)$}

With a variety of favorite foods, favorite drinks are also variously available ranging from hot to cold drinks. As shown in Table 4.

Table 3. Composition of favorite food assessment

\begin{tabular}{ccc}
\hline Number of favorite foods & Grade & Rating \\
\hline$>4$ & Very Good & 4 \\
$2-3$ & Good & 3 \\
1 & Fair & 2 \\
None & Poor & 1 \\
\hline
\end{tabular}

Table 4. Composition of favorite drink assessment

\begin{tabular}{ccc}
\hline Number of favorite drinks & Grade & Rating \\
\hline$\geq 3$ & Very Good & 4 \\
2 & Good & 3 \\
1 & Fair & 2 \\
None & Poor & 1 \\
\hline
\end{tabular}

\subsubsection{Criteria for number of visitors per day (C5)}

A large number of visitors to a restaurant will determine customers' trust in food and beverage cuisine in terms of good taste, comfort place, and customer satisfaction. As shown in Table 5. 


\subsubsection{Food price criteria (C6)}

The price of food is essential for customers who will visit a restaurant. Based on the data in the field, the more delicious and tasty a food menu, the higher the price is. Moreover, most favorite food is different from other types of food. As shown in Table 6.

Table 5. Composition of visitors per day assessment

Table 6. Composition of food price assessment

\begin{tabular}{|c|c|c|c|c|c|}
\hline Number of visitors & Grade & Rating & Food prices & Grade & Rating \\
\hline$\geq 1000$ & Very Good & 4 & $10.000-20.000$ & Very Cheap & 4 \\
\hline$\geq 300$ & Fair & 2 & $51.000-100.000$ & Expensive & 2 \\
\hline
\end{tabular}

\subsubsection{Visitor age segment criteria $(\mathrm{C} 7)$}

Table 7.

Food restaurants of visitor age segments vary depending on the tastes of each visitor. As shown in

\subsubsection{Facility criteria $(\mathbf{C 8})$}

Food restaurants that have complete facilities such as Musholla (prayer rooms), toilets, large parking lots, and the present place to eat food or drink on the floor will be much in demand by visitors, because of the comfortable and safe atmosphere. As shownn in Table 8.

Table 7. Composition of visitor age segment

\begin{tabular}{ccc}
\multicolumn{3}{c}{ assessment } \\
\hline Visitor age segment & Grade & Rating \\
\hline All Ages & Very Good & 4 \\
Adult & Good & 3 \\
Adolescent & Fair & 2 \\
Children & Poor & 1 \\
\hline
\end{tabular}

Table 8. Composition of facility assessments

\begin{tabular}{ccc}
\hline Facility & Grade & Rating \\
\hline Musholla, Toilets, Parking Lots & Very Good & 4 \\
Toilets, Parking Lots & Good & 3 \\
Parking Lots & Fair & 2 \\
None & Poor & 1 \\
\hline
\end{tabular}

\subsubsection{Online index criteria (C9)}

Online Index is a star-shaped rating of a value given by a customer to a restaurant with a complete menu. A star rating is beneficial in maintaining the best service standards. It also helps Restaurant in maintaining customer satisfaction using this system service. As shown in Table 9.

Table 9. Composition of the online index assessment

\begin{tabular}{ccc}
\hline Facility & Grade & Rating \\
\hline 5 Star & Excellent & 6 \\
4 Star & Very Good & 5 \\
3 Star & Fair & 4 \\
2 Star & Poor & 3 \\
1 Star & Bad & 2 \\
None & Very Bad & 1 \\
\hline
\end{tabular}

\subsection{Restaurant assessment data}

Based on the survey results by the research team to each restaurant owner in West Sumatra Province, the data can be obtained for processing using the Hybrid MADM method. The data obtained in the field as shown in Table 10.

The data obtained in Table 10 needs to be carried out as a conversion process based on the matching criteria rating value. Data conversion is matched based on the range of data into a rating value in the match rating value table of each of the criteria. The converted data value is used to determine the normalization matrix in the fifth step later. The results of the conversion value as shown in Table 11. 
Table 10. Restaurant assessment data

\begin{tabular}{cccccccccr}
\hline \multirow{2}{*}{ Alternatives } & \multicolumn{10}{c}{ Criteria } \\
\cline { 2 - 9 } & C1 & C2 & C3 & C4 & C5 & C6 & C7 & C8 & C9 \\
\hline RM-A & YES & 14 & 1 & 2 & $\geq 1000$ & 35.000 & All age & M, T, P & Star 5 \\
RM-B & YES & 7 & 1 & 1 & $\geq 500$ & 20.000 & All age & P & Star 4 \\
RM-C & YES & 7 & 1 & 1 & $\geq 500$ & 25.000 & Adolescent & T, P & Star 4 \\
RM-D & YES & 4 & 2 & 1 & $\geq 300$ & 20.000 & Adult & M, T, P & Star 4 \\
RM-E & YES & 14 & 2 & 3 & $\geq 250$ & 18.000 & All age & M, T, P & Star 4 \\
RM-F & No & 12 & 3 & 1 & $\geq 100$ & 15.000 & Adult & T, P & Star 3 \\
RM-G & YES & 5 & 2 & 3 & $\geq 1000$ & 25.000 & All age & T, P & Star 4 \\
RM-H & No & 8 & 4 & 2 & $\geq 300$ & 20.000 & All age & P & Star 4 \\
RM-I & YES & 6 & 1 & 1 & $\geq 1000$ & 25.000 & All age & M, T, P & Star 5 \\
\hline
\end{tabular}

Table 11. Conversion of assessment data

\begin{tabular}{cccccccccc}
\hline \multirow{2}{*}{ Alternatives } & \multicolumn{10}{c}{ Criteria } \\
\cline { 2 - 10 } & C1 & C2 & C3 & C4 & C5 & C6 & C7 & C8 & C9 \\
\hline RM-A & 3 & 4 & 2 & 3 & 4 & 3 & 4 & 4 & 6 \\
RM-B & 3 & 2 & 2 & 2 & 3 & 4 & 4 & 2 & 5 \\
RM-C & 3 & 2 & 2 & 2 & 3 & 3 & 2 & 3 & 5 \\
RM-D & 3 & 2 & 3 & 2 & 2 & 4 & 3 & 4 & 5 \\
RM-E & 3 & 4 & 3 & 4 & 1 & 4 & 4 & 4 & 5 \\
RM-F & 1 & 3 & 3 & 2 & 1 & 4 & 3 & 3 & 4 \\
RM-G & 3 & 2 & 3 & 4 & 4 & 3 & 4 & 3 & 5 \\
RM-H & 1 & 3 & 4 & 3 & 2 & 4 & 4 & 2 & 5 \\
RM-I & 3 & 2 & 2 & 2 & 4 & 3 & 4 & 4 & 6 \\
\hline
\end{tabular}

\subsection{Hybrid method calculation process}

- $\quad$ First Step: Making pairwise comparison matrix criteria. Comparison is based on the "judgment" of the decision-maker by assessing the level of importance of an element compared to other elements.

Table 12 this is obtained from the paired criteria, namely, nine paired criteria, and then given a value according to the value of the pairwise comparison scale based on Table 11 . C1 criteria are paired with $\mathrm{C} 2$ with a value of 3 , and $\mathrm{C} 1$ with $\mathrm{C} 3$ with a value of 5 . For numbers the value of 1 is obtained from the division process; for example, the criteria pair $\mathrm{C} 2$ and $\mathrm{C} 1$ with a value of 0.33 obtained from the division process, namely $1 / 3=0.33$.

Table 12. Pairwise comparison matrix

\begin{tabular}{cccccccccc}
\hline Criteria & C1 & C2 & C3 & C4 & C5 & C6 & C7 & C8 & C9 \\
\hline C1 & 1 & 3 & 5 & 7 & 3 & 2 & 4 & 5 & 6 \\
C2 & 0,33 & 1 & 2 & 5 & 3 & 4 & 6 & 5 & 7 \\
C3 & 0,2 & 0,5 & 1 & 3 & 5 & 2 & 3 & 7 & 5 \\
C4 & 0,14 & 0,2 & 0,33 & 1 & 2 & 4 & 3 & 5 & 7 \\
C5 & 0,33 & 0,33 & 0,2 & 0,5 & 1 & 4 & 5 & 2 & 3 \\
C6 & 0,5 & 0,25 & 0,5 & 0,25 & 0,25 & 1 & 3 & 5 & 7 \\
C7 & 0,25 & 0,17 & 0,33 & 0,33 & 0,2 & 0,33 & 1 & 3 & 5 \\
C8 & 0,2 & 0,2 & 0,14 & 0,2 & 0,5 & 0,2 & 0,33 & 1 & 5 \\
C9 & 0,17 & 0,14 & 0,2 & 0,14 & 0,33 & 0,14 & 0,2 & 0,2 & 1 \\
\hline Total & 3,12 & 5,79 & 9,7 & 17,42 & 15,28 & 17,67 & 25,53 & 33,2 & 46 \\
\hline
\end{tabular}

- $\quad$ Second Step: Calculating the value weight matrix between criteria and priority.

Table 13 this is obtained matrix of value weight between criteria and priorities based on calculation from Table 12. The criteria pair $\mathrm{C} 1$ and $\mathrm{C} 2$ with a value of 0.321 obtained from the division process with the sum score on that coloum, namely $1 / 3,12=0.321$.

The value weighting matrix between the criteria and priority in Table 14 is the process of determining the priority value or weight of each criterion. The weight value is used later in the multiplication process with the normalization matrix value in step six. The process of determining the weighting matrix of values among criteria is in three steps. First, each value in Table 14 is divided by the number of values per column; for example, the value 0.321 is obtained from $1 / 3,12=0.321$. Second, all the criteria values of each row added results in the Total column. Last step, the value in the Amount column divided by many criteria will produce the value in the priority column or weight. 
Table 13. Matrix of value weight between criteria and priorities

\begin{tabular}{cccccccccccc}
\hline Criteria & C1 & C2 & C3 & C4 & C5 & C6 & C7 & C8 & C9 & Qty & Priority \\
\hline C1 & 0,321 & 0,518 & 0,515 & 0,402 & 0,196 & 0,113 & 0,157 & 0,151 & 0,130 & 2,503 & 0,278 \\
C2 & 0,106 & 0,173 & 0,206 & 0,287 & 0,196 & 0,226 & 0,235 & 0,151 & 0,152 & 1,732 & 0,192 \\
C3 & 0,064 & 0,086 & 0,103 & 0,172 & 0,327 & 0,113 & 0,118 & 0,211 & 0,109 & 1,303 & 0,145 \\
C4 & 0,045 & 0,035 & 0,034 & 0,057 & 0,131 & 0,226 & 0,118 & 0,151 & 0,152 & 0,948 & 0,105 \\
C5 & 0,106 & 0,057 & 0,021 & 0,029 & 0,065 & 0,226 & 0,196 & 0,060 & 0,065 & 0,825 & 0,092 \\
C6 & 0,160 & 0,043 & 0,052 & 0,014 & 0,016 & 0,057 & 0,118 & 0,151 & 0,152 & 0,763 & 0,085 \\
C7 & 0,080 & 0,029 & 0,034 & 0,019 & 0,013 & 0,019 & 0,039 & 0,090 & 0,109 & 0,432 & 0,048 \\
C8 & 0,064 & 0,035 & 0,014 & 0,011 & 0,033 & 0,011 & 0,013 & 0,030 & 0,109 & 0,320 & 0,036 \\
C9 & 0,054 & 0,024 & 0,021 & 0,008 & 0,022 & 0,008 & 0,008 & 0,006 & 0,022 & 0,172 & 0,019 \\
\hline
\end{tabular}

Table 14. Total addition value

\begin{tabular}{cccc}
\hline Criteria & Priority & Amount & Result \\
\hline C1 & 0,278 & 10,013 & 10,291 \\
C2 & 0,192 & 6,415 & 6,607 \\
C3 & 0,145 & 3,866 & 4,011 \\
C4 & 0,105 & 2,389 & 2,494 \\
C5 & 0,092 & 1,500 & 1,592 \\
C6 & 0,085 & 1,504 & 1,589 \\
C7 & 0,048 & 0,510 & 0,558 \\
C8 & 0,036 & 0,277 & 0,312 \\
C9 & 0,019 & 0,048 & 0,067 \\
& Total & & 27,521 \\
\hline
\end{tabular}

- $\quad$ Third Step: Calculating the sum of each line's matrix

Table 15 this is addition matrix for each line based on calculation from Table 13. The criteria pair $\mathrm{C} 1$ and $\mathrm{C} 2$ with a value of 0.278 obtained from the multiplication process with 1 (from Table 12) x0.278 (from Table 13), namely $1 \times 0.278=0.278$.

Table 15. Addition matrix for each line

\begin{tabular}{ccccccccccr}
\hline Criteria & C1 & C2 & C3 & C4 & C5 & C6 & C7 & C8 & C9 & Qty \\
\hline C1 & 0,278 & 0,834 & 1,391 & 1,947 & 0,834 & 0,556 & 1,113 & 1,391 & 1,669 & 10,013 \\
C2 & 0,064 & 0,192 & 0,385 & 0,962 & 0,577 & 0,77 & 1,155 & 0,962 & 1,347 & 6,415 \\
C3 & 0,029 & 0,072 & 0,145 & 0,434 & 0,724 & 0,29 & 0,434 & 1,014 & 0,724 & 3,866 \\
C4 & 0,015 & 0,021 & 0,035 & 0,105 & 0,211 & 0,422 & 0,316 & 0,527 & 0,738 & 2,389 \\
C5 & 0,03 & 0,03 & 0,018 & 0,046 & 0,092 & 0,367 & 0,458 & 0,183 & 0,275 & 1,500 \\
C6 & 0,042 & 0,021 & 0,042 & 0,021 & 0,021 & 0,085 & 0,254 & 0,424 & 0,593 & 1,504 \\
C7 & 0,012 & 0,008 & 0,016 & 0,016 & 0,01 & 0,016 & 0,048 & 0,144 & 0,24 & 0,510 \\
C8 & 0,007 & 0,007 & 0,005 & 0,007 & 0,018 & 0,007 & 0,012 & 0,036 & 0,178 & 0,277 \\
C9 & 0,003 & 0,003 & 0,004 & 0,003 & 0,006 & 0,003 & 0,004 & 0,004 & 0,019 & 0,048 \\
\hline
\end{tabular}

The addition matrix for each row is based on calculations from Table 12 and Table 13. All the values in Table 12 are multiplied by the priority column in Table 13. After the addition matrix for each row is obtained, it can be easier to determine the maximal total value process in the next step.

- $\quad$ Fourth Step: Calculating the value of the criteria consistency ratio

The total value is the sum of the priority values in Table 15 and the total value in Table 14. The total process value of this added value will be continued in determining the maximum value of lamda, consistency index $(\mathrm{CI})$, and consistency ratio (CR).

$$
\begin{aligned}
& \lambda \text { Maks }=\frac{27,521}{9}=3.058 \\
& C I(\text { Consistency Index })=\frac{\lambda M a k s-n}{n-1}=\frac{3.058}{9-1}=\frac{-5.942}{8}=-0.74275 \\
& C R(\text { Consistency Ratio })=\frac{C I}{I R}=\frac{-0.74275}{1,45}=-0,512
\end{aligned}
$$

Because the $\mathrm{CR}$ value $=-0.512<0.1$, the consistency ratio of the calculation is acceptable. 
- $\quad$ Fifth Step: Determining the normalization matrix Normalization matrix:
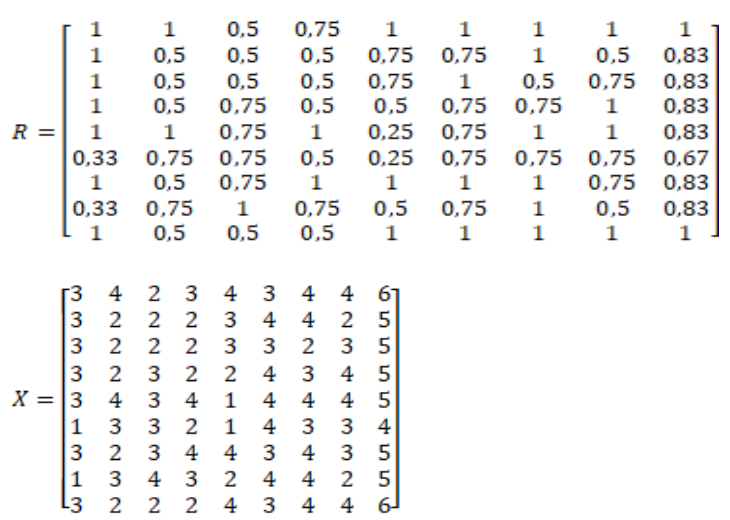

- $\quad$ Sixth Step: Determining the preference Value (Vi), Formula:

$$
\mathrm{V}_{\mathrm{i}}=\sum_{\mathrm{j}=1}^{\mathrm{n}} \mathrm{w}_{\mathrm{j}} \mathrm{r}_{\mathrm{ij}}
$$

$\mathrm{W}=[0.278,0.192,0.145,0.105,0.092,0.085,0.048,0.036,0.019]$

- Seventh Step: Rank the results

The result of the process from this hybrid DSS after the sixth step is the rank of nine restaurants. The highest value is in V1 so that the alternative RM-A with a score of 2,294 is the alternative chosen as the best alternative. In other words, RM-A will be recommended as a halal culinary tourism in West Sumatra. The second highest value is in V2 so that RM-B with a score of 1,215 is the second alternative. The third highest value is in V3 so that RM-C with a score of 0,918 is the third alternative. The fourth highest value is in V4 so that RM-E with a score of 0,697 is the fourth alternative. The fifth highest value is in V5 so that RM-D with a score of 0,691 is the five alternatives. The sixth highest value is in V6 so that RM-F with a score of 0,468 is the sixth alternative. The seventh highest value is in V7 so that RM-G with a score of 0,376 is the seventh alternative. The eighth highest value is in V8 so that RM-H with a score of 0,231 is the eighth alternative. The lowest value is in V4 so that RM-I with a score of 0,238 is the ninth alternative.

\section{CONCLUSION}

After analyzing the decision support system for West Sumatra halal food recommendation using the hybrid MADM method, it can be concluded that: DSS applications made using the hybrid DSS method can combine analytical hierarchy process (AHP) and simple additive weighting (SAW) methods, so that they easily recommend halal culinary tourism in West Sumatra. By implementing analytical hierarchy process (AHP) method, it can determine a consistent weight value of each criterion, where the weight value will be used in the sum of preference values in simple additive weighting (SAW) method. By using a decision support system, simple additive weighting (SAW) method carried out the normalization calculation, then multiplied by the weight value (W) that has been determined to get the preference value of each criterion. Furthermore, the ranking value is obtained from the alternatives by adding up the value of the preference. This ranking value determines the West Sumatra halal culinary tourism recommendations. Decision support systems using the hybrid MADM method in real terms can be applied in the West Sumatra halal culinary tourism recommendations. For researchers who want to develop this decision support system, it can be developed further by combining other DSS methods to be better and more varied by completing the criteria for halal culinary tourism recommendations in West Sumatra, so that the analysis results are sharper and valid.

\section{ACKNOWLEDGEMENTS}

We would like to express our immeasurable gratitude to Mr. H. Herman Nawas and Mrs. Dr. Hj. Zerni Melmusi, M.M., Ak. CA. as Chairman of the Foundation and founder of the Yayasan Pendidikan 
Komputer (YPTK) Padang which oversees the Universitas Putra Indonesia YPTK Padang who has provided us with funding and support for this research. Thank are also given to all the academics of the Universitas Putra Indonesia YPTK Padang who have supported this research and the tourism office of the City of Padang and West Sumatra Province who have permitted to carry out this research.

\section{REFERENCES}

[1] J. Aslan Ceylan and A. O. Ozcelik, "Cuisine culture of the pearl of Mesopotamia: Mardin, Turkey," J. Ethn. Foods, vol. 5, no. 4, pp. 239-245, 2018, doi: 10.1016/j.jef.2018.10.001

[2] S. T. Wang, "When Chinese cuisine meets western wine," Int. J. Gastron. Food Sci., vol. 7, pp. 32-40, 2017, doi: 10.1016/j.ijgfs.2016.11.003.

[3] B. Llamazares, "Using interval weights in MADM problems," Comput. Ind. Eng., vol. 136, no. July, pp. 345-354, 2019, doi: 10.1016/j.cie.2019.07.035.

[4] K. Kumar, "A Spectrum Handoff Scheme for Optimal Network Selection in NEMO based Cognitive Radio Vehicular Networks: A Cost Function MADM Method based on Grey Theory based Approach," Procedia Comput. Sci., vol. 125, pp. 275-281, 2018, doi: 10.1016/j.procs.2017.12.037.

[5] S. Saputra, "Fuzzy MADM Model AHP Method as Media Information Systems Department," STMIK Pringsewu Lampung," no. 09.

[6] H. Wibowo S, "Madm-tool: The sensitivity test application for the MADM model uses the SAW and TOPSIS method.," Semin. Nas. Apl. Teknol. Inf., vol. 0, no. 0, 2010.

[7] A. ; A. F. R. Arifin, "Implementation of the Attribute Decision Making (FMADM) Method to Determine Mangrove Planting Areas," Sains, Teknol. dan Ind., vol. 14, no. 1, pp. 87-88, 2006.

[8] R. E. Setyani and R. Saputra, "Flood-prone Areas Mapping at Semarang City by Using Simple Additive Weighting Method," Procedia - Soc. Behav. Sci., vol. 227, no. November 2015, pp. 378-386, 2016, doi: 10.1016/j.sbspro.2016.06.089.

[9] R. Al-husain and R. Khorramshahgol, "Incorporating Analytical Hierarchy Process and Goal Programming to Design Responsive and Efficient Supply Chains," Oper. Res. Perspect., p. 100149, 2020, doi: 10.1016/j.orp.2020.100149.

[10] S. Zhou and P. Yang, "Risk management in distributed wind energy implementing Analytic Hierarchy Process," Renew. Energy, vol. 150, pp. 616-623, 2020, doi: 10.1016/j.renene.2019.12.125.

[11] M. Karatas, "Hydrogen energy storage method selection using fuzzy axiomatic design and analytic hierarchy process," Int. J. Hydrogen Energy, no. xxxx, 2019, doi: 10.1016/j.ijhydene.2019.11.130.

[12] R. Helilintar, W. W. Winarno, and H. Al Fatta, "Application of SAW and Fuzzy Methods in the Scholarship Acceptance Decision Support System," Creat. Inf. Technol. J., vol. 3, no. 2, p. 89, 2016, doi: 10.24076/citec.2016v3i2.68.

[13] H. T. Sihotang and M. Siboro, "Application of Decision Support System for Determination of Problematic Students Using the Saw Method at the Mulia Pratama Private Junior High School, Medan," J. Informatics Pelita Nusant., vol. 1, no. 1, pp. 1-6, 2016.

[14] M. Mailasari, "Multi Attribute Decision Making Model Simple Additive Weighting Method in Determining Loan Recipients," J. Tek. Komput., vol. 2, no. 1, pp. 100-105, 2016.

[15] S. P. Jurusan and C. F. Putri, "Selection of Raw Material Suppliers for Packaging Using the AHP (Analytical Hierarchy Process) Method," Widya Tek., vol. 20, no. 1, pp. 25-31, 2012.

[16] J. Lemantara, N. A. Setiawan, and M. N. Aji, "Designing Decision Support System for Achieving Student Selection Using AHP and Promethee Methods," Jnteti, vol. 2, no. 4, pp. 20-28, 2013.

[17] M. E. Lestiani, "Promotional Dominant Factors That Affect Consumer Motivation In Buying A Product Using The Ahp Method" Ind. Elektro Penerbangan, vol. 1, pp. 15-20, 2011.

[18] A. S. Putra, D. R. Aryanti, and I. Hartati, "The SAW (Simple Additive Weighting) Method as a Decision Support System for Outstanding Teachers (Case Study: SMK Global Surya),” Pros. Semin. Nas. Darmajaya, vol. 1, no. 1, pp. 85-97, 2018.

[19] D. Darmastuti, "Implementation of the Simple Additive Weighting (SAW) Method in a Web-Based Job Vacancy Information System," J. Sist. dan Teknol. Inf., vol. 16, no. 2, pp. 1-6, 2012.

[20] D. F. Li, "A ratio ranking method of triangular intuitionistic fuzzy numbers and its application to MADM problems," Comput. Math. with Appl., vol. 60, no. 6, pp. 1557-1570, 2010, doi: 10.1016/j.camwa.2010.06.039.

[21] A. Arifia, A. A. Suryanto, and H. Prastyo, "Design of a Priority Decision Support System for Electric Transformer Repair using the Simple Additive Weighting (SAW) Method," INOVTEK Polbeng - Seri Inform., vol. 2, no. 1, p. 1, 2017, doi: 10.35314/isi.v2i1.110.

[22] H. Hendri, S. Enggari, Mardison, M. R. Putra, and L. N. Rani, "Automatic System to Fish Feeder and Water Turbidity Detector Using Arduino Mega," J. Phys. Conf. Ser., vol. 1339, no. 1, 2019, doi: 10.1088/17426596/1339/1/012013.

[23] A. P. Gusman and H. Hendri, "Expert system to diagnose child development growth disorders with forward chaining method," J. Phys. Conf. Ser., vol. 1339, no. 1, 2019, doi: 10.1088/1742-6596/1339/1/012045.

[24] E. Karahalil, "Principles of halal-compliant fermentations: Microbial alternatives for the halal food industry," Trends in Food Science \& Technology. vol 98. pp. 1-9. 2019, https://doi.org/10.1016/j.tifs.2020.01.031. 
[25] Al-Ansi, H. G. T. Olya, H. Han, "Effect of general risk on trust, satisfaction, and recommendation intention for halal food," International Journal of Hospitality Management, vol. 83, pp. 210-219. 2019, https://doi.org/10.1016/j.ijhm.2018.10.017.

[26] N. A. Rakhmawati, J. Fatawi, A. C. Najib, A. A. Firmansyah, "Linked open data for halal food products," Journal of King Saud University - Computer and Information Sciences, vol. 20, pp. 56-67. 2019, https://doi.org/10.1016/j.jksuci.2019.04.004.

\section{BIOGRAPHIES OF AUTHORS}

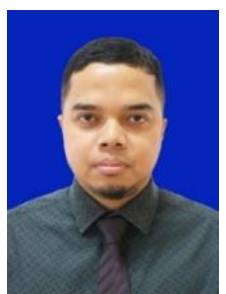

Mardison a researcher, and a lecturer. I was born at Sawah Lunto, on 03 July 1986. I was studying for a bachelor's and master's degree in UPI YPTK Padang majoring in computer science. I got a degree S.Kom., M.Kom from that University. My email address is mardison@upiyptk.ac.id. You can contact me at number +6281266634234. My office place is at University Putra Indonesia YPTK Padang, Lubuk Begalung Street, Padang, Sumatera Barat, Indonesia. My expertise is artificial intelligent and web programming.

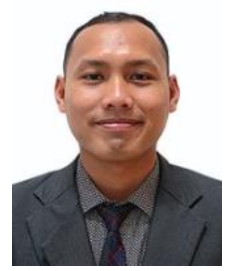

Agung Ramadhanu a researcher, and a lecturer. I was born at Muaro Bungo, on 15 April 1991. I was studying for a bachelor's and master's degree in UPI YPTK Padang majoring in computer science. I got a degree S.Kom., M.Kom from that University. My email address is agung_ramadhanu@upiyptk.ac.id. You can contact me at number +6285266111669. My office place is at University Putra Indonesia YPTK Padang, Lubuk Begalung Street, Padang, Sumatera Barat, Indonesia. My expertise is decision support systems and artificial intelligent.

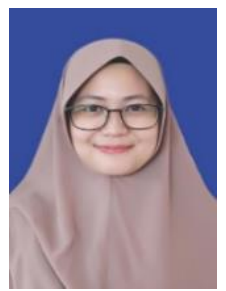

Larissa Navia Rani a researcher, and a lecturer. I was born at Padang, on 20 November 1992. I was studying for a bachelor's and master's degree in UPI YPTK Padang majoring in computer science. I got a degree S.Kom., M.Kom from that University. My email address is larissa_navia_rani@upiyptk.ac.id. You can contact me at number +6281363908833. My office place is at University Putra Indonesia YPTK Padang, Lubuk Begalung Street, Padang, Sumatera Barat, Indonesia. My expertise is discrete mathematics.

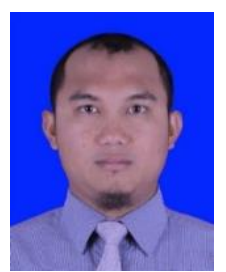

Larissa Sofika Enggari a researcher, and a lecturer. I was born at Simalanggang, on 16 March 1986. I was studying for a bachelor's and master's degree in UPI YPTK Padang majoring in computer science. I got a degree S.Kom., M.Kom from that University. My email address is sofika_enggari@upiyptk.ac.id. You can contact me at number +6281363908833. My office place is at University Putra Indonesia YPTK Padang, Lubuk Begalung Street, Padang, Sumatera Barat, Indonesia. My expertise is e-commerce and information system management. 